\title{
Localization of androgen receptors in ram epididymal principal cells*
}

\author{
F. R. Tekpetey†, D. N. R. Veeramachaneni and R. P. Amann \\ Animal Reproduction Laboratory, Colorado State University, Fort Collins, Colorado 80523, USA
}

\begin{abstract}
Summary. Androgen receptor was immunolocalized in the epididymal epithelium of rams and in isolated cells using an antibody against a synthetic polypeptide representing a portion of the androgen receptor. Immunostaining was predominant in the epithelium in tissue sections. Concentrations of androgen receptor were determined in cells from the central caput, distal caput, and central corpus epididymidis enzymically dissociated and elutriated to provide two fractions. On the average $(n=18)$, Fraction I contained $8 \%$ principal cells while Fraction II contained $71 \%$ principal cells; the stromal cells in each fraction were primarily smooth muscle and fibroblasts. For each sample, the number of DHT receptors $(\mathrm{fmol})$ per $10^{6}$ total cells was greater in Fraction II than in Fraction I. Few cells in Fraction I were immunostained for androgen receptor, whereas most cells in Fraction II were intensely stained. The numbers of DHT receptors per cell, or per principal cell, were similar for the central caput and distal caput, but lower in the central corpus epididymidis. The results support our hypothesis that most epididymal DHT receptors are localized in principal cells and confirm that the region between the central caput and proximal corpus of the ram epididymis is most dependent on androgen stimulation.
\end{abstract}

Keywords: epididymis; androgen receptor; principal cells; ram

\section{Introduction}

Functions of the epididymal epithelium, and especially sperm maturation, are androgen-dependent (Amann, 1987; Robaire \& Hermo, 1988), possibly through local action of dihydrotestosterone (DHT). The enzyme that converts testosterone to DHT, $5 \alpha$-reductase, apparently is localized in principal cells (Klinefelter \& Amann, 1980). In rams (Amann, 1987; Amann et al., 1987), in contrast to rats (Robaire \& Hermo, 1988), the activity of $5 \alpha$-reductase is negligible in the initial segment, high in the central caput through to the proximal corpus, and lower in the central corpus epididymidis. Androgen receptor in ram epididymal tissue follows a similar distribution, although the concentration of oestradiol receptor in whole epididymal tissue is greater in the cauda than in the caput epididymidis (Tekpetey \& Amann, 1988a). Androgen receptor is present in rat and rabbit epididymal tissue (Ritzen et al., 1971; Hansson et al., 1973; Danzo et al., 1973; Danzo \& Eller, 1975), but its regional distribution has not been quantified. At least in ram epididymal tissue, the androgen receptor is highly specific for DHT (Tekpetey \& Amann, 1988a), so hereafter it will be referred to interchangeably as androgen or DHT receptor.

Androgen-dependent mRNAs are present in rat epididymal tissue (Brooks et al., 1986; Brooks, 1987), and principal cells secrete proteins into the milieu around spermatozoa within the epididymal duct, which presumably mediate androgen-dependence of sperm maturation (Amann,

* Reprint requests to R. P. Amann.

$\dagger$ Present address: Department of Obstetrics and Gynecology, The University of Western Ontario, London, Ontario, Canada N6A 5A5. 
1987, 1988; Robaire \& Hermo, 1988). It is possible that the DHT receptor is localized in principal cells. This concept is supported by autoradiographic evaluations of epididymal tissue from mice injected with $\left[{ }^{3} \mathrm{H}\right] \mathrm{DHT}$ (Schleicher et al., 1984). Principal cells in the caput and cauda epididymidis of mice were heavily labelled with $\left[{ }^{3} \mathrm{H}\right] \mathrm{DHT}$, compared to smooth muscle and connective tissue associated with the duct.

Based on the regional distribution of receptors for DHT in the ram epididymis (Tekpetey \& Amann, 1988a), we proposed that principal cells from the caput or corpus epididymidis would have a high number of DHT receptors relative to stromal cells (i.e. smooth muscle or fibroblasts). Therefore, we measured the numbers of DHT receptors in two populations of epididymal cells that contained relatively high or low percentages of principal cells. We also studied localization of androgen receptor in epididymal tissue and elutriated cells using an antibody against the androgen receptor.

\section{Materials and Methods}

Preparation of tissue and cellular populations. Tissues from the efferent ducts, caput, corpus and cauda epididymidis (Fig. 1), and liver were collected from 3 adult Western range rams. Tissues were fixed in Bouin's solution for $24 \mathrm{~h}$, immersed in $70 \%$ ethanol for $\mathbf{4 8} \mathrm{h}$, dehydrated in graded ethanols and embedded in paraffin wax. Sections $(6 \mu \mathrm{m})$ were cut and serially collected on glass slides coated with Histostik (Accurate Chemical Corporation, Westbury, NY, USA) for immunostaining.

Epididymal tissue was obtained from 6 other adult Western range rams by castration, under local anaesthesia, in October and November. Tissue representing the central caput, distal caput and central corpus (Fig. 1) was taken from each epididymis and 2-3 g of epididymal duct were teased from the saccus epididymidis, weighed and processed for isolation of fractions enriched for, or relatively devoid of, principal cells (Wagley et al., 1984). These regions were selected because they have the highest concentration of androgen receptor in total tissue (Tekpetey \& Amann, 1988a). The procedures for processing tissue fragments to produce a suspension of individual cells, and subsequent fractionation of this cellular suspension by elutriation, were essentially as described by Wagley et al. (1984) and Amann et al. (1987).

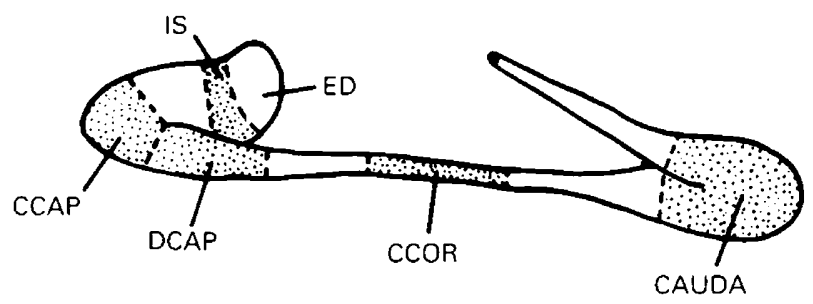

Fig. 1. Sites where samples of epididymal tissue were taken for immunohistochemistry and/or enzymic dissociation and elutriation. Regions are designated as efferent ducts, ED; initial segment, IS; central caput, CCAP; distal caput, DCAP; central corpus, CCOR; and cauda epididymidis, CAUDA.

A Beckman JE-6B elutriator rotor, fitted with a Sanderson chamber, was used to prepare two fractions. Fraction I consisted of cells eluted in the first $200 \mathrm{ml}$ after loading cells into the elutriation chamber at $1600 \mathrm{rev} . / \mathrm{min}$ using a flow rate of $15.5 \mathrm{ml} / \mathrm{min}$ for the caput or $16.0 \mathrm{ml} / \mathrm{min}$ for the corpus epididymidis. Fraction II was cells in the next $100 \mathrm{ml}$ collected at $30 \mathrm{ml} / \mathrm{min}$ as rotor speed dropped to $0 \mathrm{rev} . / \mathrm{min}$ (Wagley et al., 1984). Cells in each fraction were concentrated by centrifugation and resuspended in 5-10 ml elutriation buffer. Fraction I contained relatively few principal cells, and the predominant cell types included smooth muscle cells, fibroblasts, basal cells and lymphocytes. Fraction II was enriched for principal cells, although contaminating cells were present. Thus, Fractions I and II were reciprocally enriched.

Concentration of cells (excluding spermatozoa) in aliquants of each suspension was determined with a haemocytometer and a phase-contrast microscope. Spermatozoa were excluded since they do not contain steroid receptors (Amann \& Hammerstedt, 1976). Aliquants of each cellular suspension were air-dried on microscope slides and held at room temperature until differentially stained or held at $-70^{\circ} \mathrm{C}$ until immunostained. 


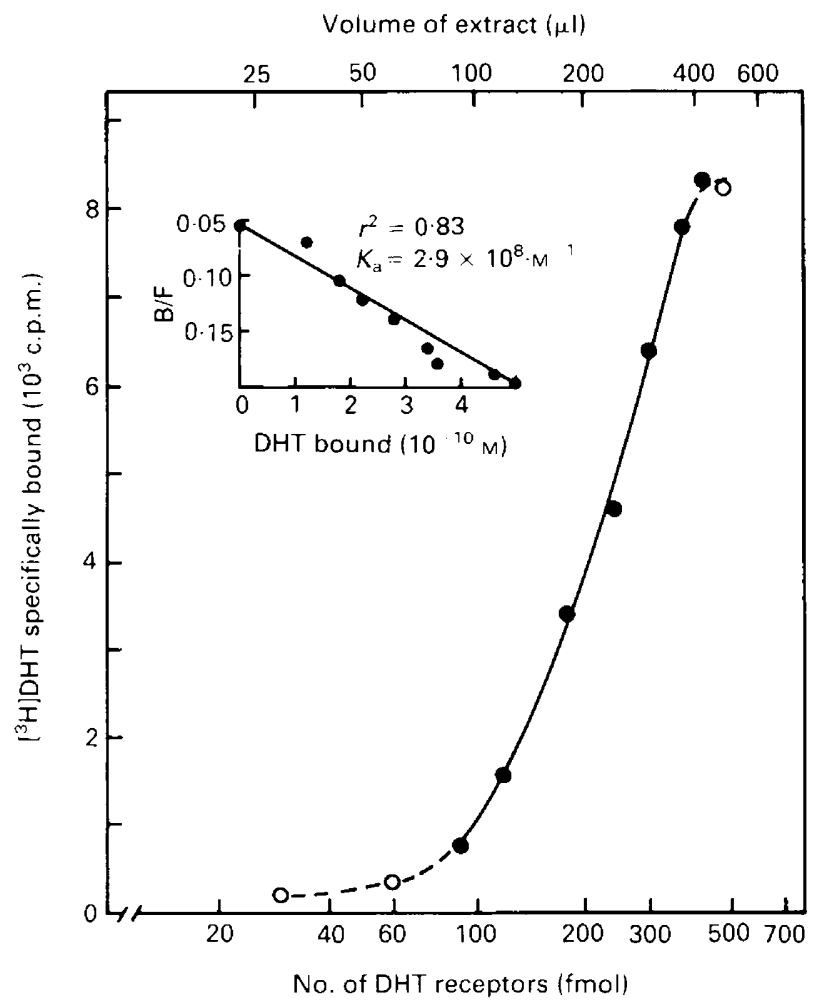

Fig. 2. Standard curve obtained by plotting counts of $\left[{ }^{3} \mathrm{H}\right] \mathrm{DHT}$ specifically bound to receptor $v s$ fmol DHT receptor in the standard extract. designated by $\bigcirc$ were excluded, $x$ was expressed as fmol DHT receptor and $y$ was expressed as c.p.m. $\left[{ }^{3} \mathrm{H}\right] \mathrm{DHT} ; r^{2}=0.97$. The insert (from Tekpetey \& Amann, 1988b) shows a Scatchard analysis of receptor content in the standard extract.

Differential and immunostaining. Air-dried smears of cellular suspensions were stained by the Papanicolaou method. At least $200 \mathrm{cells} / \mathrm{sample}$ were classified as a principal cell or other cells. Criteria for differentiating principal cells from other cells included cell size and shape, nuclear size and shape and differential staining pattern (Wagley $e t$ al., 1984).

Tissue sections and smears of cellular suspensions were utilized for immunolocalization of androgen receptor. The primary antiserum (AR1-52 donated by Dr F. S. French) was produced in rabbits against a synthetic 15-amino acid peptide sequence (Asp-His-Val-Leu-Pro-Ile-Asp-Tyr-Tyr-Phe-Pro-Pro-Gln-Lys-Thr) representing the deduced sequence of the rat androgen receptor (Tan et al., 1988) and was used with the biotin-streptavidin peroxidase procedure (Stravigen Immunohistology Kit, BioGenex Laboratories, San Ramon, CA, USA). Frozen cell smears were thawed, fixed in $4 \%$ paraformaldehyde $(0.1 \mathrm{M}$-sodium phosphate and $0.146 \mathrm{M}$-sucrose at $\mathrm{pH} 7.4)$ for $5 \mathrm{~min}$ at $22^{\circ} \mathrm{C}$, and washed in $0.01 \mathrm{M}$-potassium phosphate-buffered saline (PBS; $0.145 \mathrm{M}-\mathrm{NaCl}, \mathrm{pH} 7.4$ ) for $10 \mathrm{~min}$. Tissue sections were deparaffinized in xylene, passed through absolute ethanol and $95 \%$ ethanol for $10 \mathrm{~min}$ each, and rehydrated in PBS for $10 \mathrm{~min}$. Cell smears and tissue sections were treated with $3 \%$ hydrogen peroxide for $10 \mathrm{~min}$ at $35^{\circ} \mathrm{C}$ to reduce endogenous peroxidase activity. Slides were washed twice in PBS for $5 \mathrm{~min}$ each at $22^{\circ} \mathrm{C}$, and similarly washed after each subsequent step (except after incubation with normal goat serum). Cells and tissues were incubated sequentially in normal goat serum ( $10 \mathrm{~min}$ at $35^{\circ} \mathrm{C}$ ); rabbit anti-androgen receptor serum $(5 \mu \mathrm{g}$ protein $/ \mathrm{ml} \mathrm{PBS})$; preimmune rabbit serum, or primary antiserum preadsorbed with the synthetic sequence $\left(30 \mathrm{~min}\right.$ at $\left.35^{\circ} \mathrm{C}\right)$; biotinylated goat anti-rabbit immunoglobulin $\left(10 \mathrm{~min}\right.$ at $\left.35^{\circ} \mathrm{C}\right)$; horseradish peroxidase-labelled streptavidin $\left(10 \mathrm{~min}\right.$ at $\left.35^{\circ} \mathrm{C}\right)$ and freshly prepared substrate reagent containing hydrogen peroxide and 3-amino-9-ethylcarbazole (AEC) or diaminobenzidine tetrahydrochloride (DAB). Peroxidase indirectly bound to androgen receptor oxidized the AEC or DAB forming a brownish-red or brown precipitate. In some cases, slides were counterstained with Mayer's haematoxylin for $5 \mathrm{~min}$, dipped in ammonia water for $10 \mathrm{sec}$, and rinsed in running water. Coverslips were mounted using glycerol-gelatin. Slides were examined and photographed using a Nikon Optiphot microscope. Cells and tissues treated with preimmune rabbit serum or antiserum preadsorbed with immunogen, instead of primary antiserum, served as controls. 

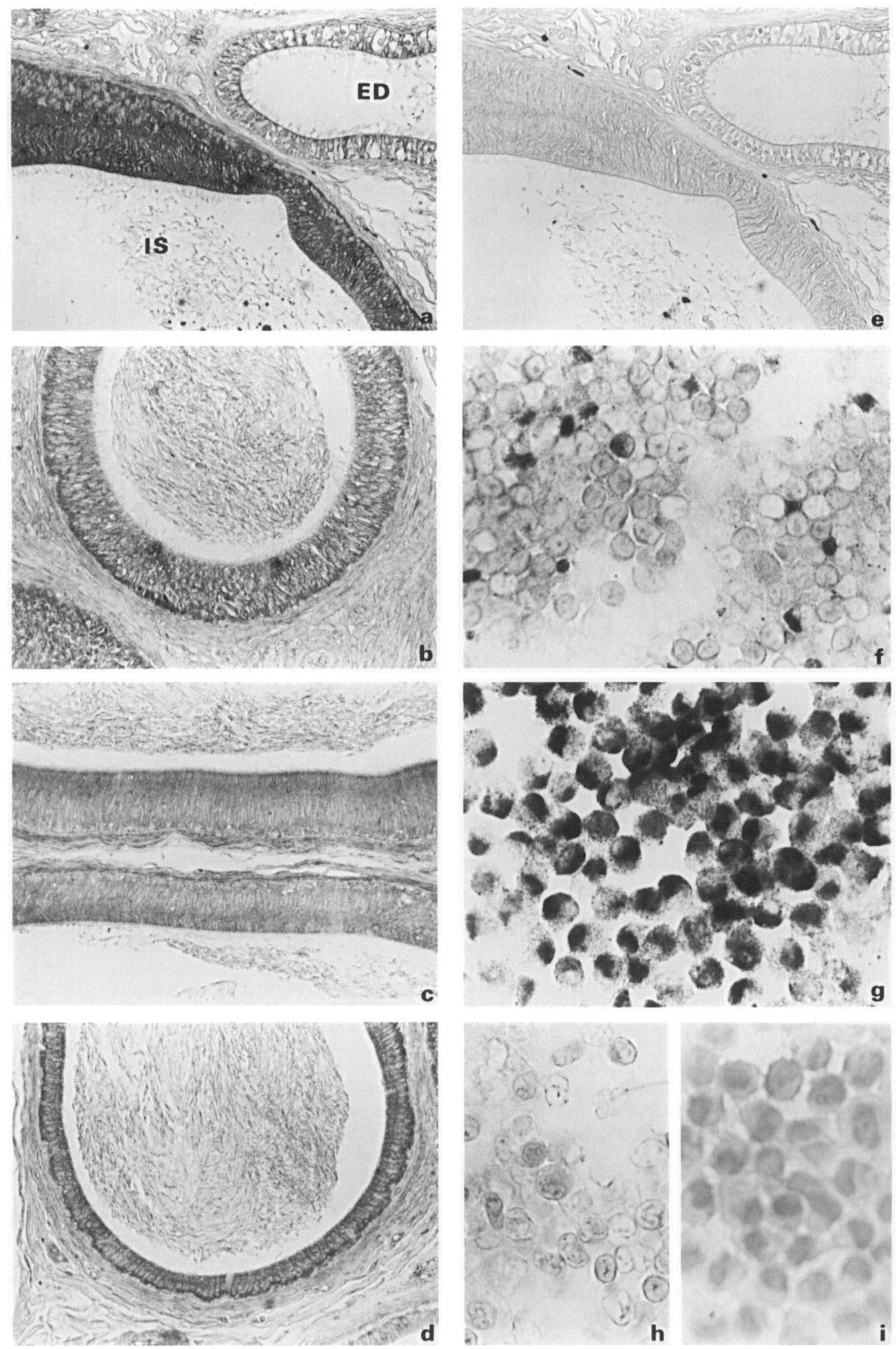
Preparation of cellular extracts. The fractions obtained by elutriation were centrifuged at $325 \mathrm{~g}$ for $10 \mathrm{~min}$ and the peiletted cells were homogenized, on ice, in low-salt TEDG buffer [ $10 \mathrm{~mm}$-Tris-HCl; $1.5 \mathrm{~mm}$-EDTA; $1.0 \mathrm{~mm}$ each of dithiothreitol, phenylmethyl sulphonyl fluoride and sodium molybdate; $10 \%(\mathrm{v} / \mathrm{v})$ glycerol; $\mathrm{pH} 7 \cdot 4]$, using a glass homogenizer $(11 \mathrm{~mm}$ diam) for 20 strokes. The homogenate was centrifuged at $30000 \mathrm{~g}$ for $30 \mathrm{~min}$ and the supernatant containing cytosolic receptor was saved. The pellet was resuspended in high-salt buffer (identical to low-salt TEDG buffer, except that it also contained $400 \mathrm{~mm}-\mathrm{KCl}$ ), held on ice and vortexed every $15 \mathrm{~min}$ for $1 \mathrm{~h}$ to extract nuclear receptors which were resistant to low-salt homogenization (Tekpetey \& Amann, 1988a). The second homogenate was centrifuged (as above) and the supernatant was saved. The two supernatants were pooled into a final volume of 3-4 ml, brought to $5 \%(\mathrm{v} / \mathrm{v})$ dimethylsulphoxide, snap-frozen in liquid nitrogen, and stored at $-70^{\circ} \mathrm{C}$ until the receptors were assayed. Before quantification of DHT receptors, endogenous steroids were removed from the extracts using a suspension of dextran-coated charcoal (Tekpetey \& Amann, 1988a).

Quantification of DHT receptor. The concentration of DHT receptor in each cellular extract was determined using a standard curve assay (Tekpetey \& Amann, 1988b). Briefly, a 7-point standard curve was established using a standard extract of ram epididymal tissue (the same as used by Tekpetey \& Amann, 1988b) that contained $6.0 \mathrm{fmol}$ DHT receptor per $1.0 \mathrm{mg}$ wet weight tissue and had a binding affinity of $3.5 \times 10^{8} \mathrm{M}^{-1}$. Increasing quantities (25-400 $\mu \mathrm{l}$, equivalent to $5-80 \mathrm{mg}$ wet tissue) of the standard extract, or a sample (200 or $300 \mu \mathrm{l})$ of the extract from a cellular fraction, were incubated (in duplicate) with $1 \cdot 5 \mathrm{nM}-\left[1,2,4,5,6,7-{ }^{3} \mathrm{H}\right] \mathrm{DHT}$ (sp. act. $128 \mathrm{Ci} / \mathrm{mmol}$ ). Parallel tubes contained a 100-fold excess of non-radioactive DHT to enable calculation of non-specific binding. After $30 \mathrm{~h}$ incubation at $4^{\circ} \mathrm{C}$, free steroid was separated from receptor-bound steroid by adding $500 \mu l$ dextran-coated charcoal $\left[0.6 \%(\mathrm{w} / \mathrm{v})\right.$ charcoal and $0.06 \%(\mathrm{w} / \mathrm{v})$ dextran in TEDG buffer]. After incubation for $10 \mathrm{~min}$ at $4^{\circ} \mathrm{C}$, followed by centrifugation at $5000 \mathrm{~g}$ for $10 \mathrm{~min}$, a $600-\mu \mathrm{l}$ sample of supernatant was added to $4 \mathrm{ml}$ scintillation fluid. All samples were counted for $5 \mathrm{~min}$.

Values for duplicate tubes were averaged and specific binding (primary value minus value for non-specific binding) was calculated for each volume of standard extract or extract of a cellular fraction. From the known concentration of DHT receptor in the standard extract, the number of receptors (fmol) for each volume of standard extract was calculated; these values were plotted to provide a standard curve (Fig. 2). The amount of $\left[{ }^{3} \mathrm{H}\right] \mathrm{DHT}$ specifically bound to a known volume of an extract from a cellular fraction was compared to the standard curve and the concentration of DHT receptor in the sample extract was calculated. Values for all samples were within the linear portion of the standard curve, between 100 and $250 \mathrm{fmol}$ DHT receptor per assay tube. All cellular extracts were analysed for DHT receptor in one assay. Intra-assay variation, based on values for the duplicate tubes for each sample, was $2 \cdot 7 \%$.

The amount of DHT receptor in each extract was expressed on the basis of $10^{6}$ total cells and for Fraction II on the basis of $10^{6}$ principal cells, assuming that all receptor was in principal cells. The number of principal cells in each extract was calculated from counts of total cells and the percentage that were principal cells, as determined by evaluation of PAP-stained smears, for the corresponding cellular fraction. To estimate the amount of DHT receptor that might be associated with 'other' cells, data for cell numbers and percentage of principal cells in Fraction I, and estimates of the amount of receptor per $10^{6}$ principal cells in Fraction II, were used to calculate principal cell-associated DHT receptor in Fraction $\mathbf{I}$. This value was subtracted from the measured amount to estimate that associated with 'other' cells; the resulting value was expressed per $10^{6}$ 'other' cells.

Statistical tests. The cellular fractionation and receptor data were subjected to analysis of variance (Statistical Analysis System, 1982), using a model that included region of the epididymis (fixed), cellular fraction (fixed), replicate (ram; random) and the interactions of epididymal region and cellular fraction. Differences between means were tested using the Student-Neuman-Keuls multiple comparison. Data with non-homogeneous variance, as indicated by Bartlett's test, were transformed logarithmically before analysis.

Fig. 3. Immunolocalization of androgen receptor in the ovine epididymis $(\mathrm{a}-\mathrm{e} ; \times 125)$ and elutriated cells of central caput epididymidis $(\mathrm{f}-\mathrm{i} ; \times 400)$. Androgen receptor was sparse in the efferent ducts (ED), but immunostaining was very conspicuous in epithelium of the initial segment (IS) of the epididymis (a). Immunostaining also was predominant in epithelium of the central caput (b), central corpus (c), and cauda (d) epididymidis. At distal sites, some immunostaining of smooth muscle associated with the duct was evident. Immunostaining was not observed when preimmune serum (e) or antiserum preadsorbed with synthetic peptide was substituted for primary antiserum. Only a few cells were immunostained in Fraction I that was enriched for stromal cells (f), whereas a large proportion of cells was conspicuously stained in Fraction II that was enriched for principal cells (g). Immunostaining was not observed when preimmune serum $(\mathrm{h})$ or antiserum preadsorbed with the synthetic peptide (i) was substituted for primary antiserum. 


\section{Results}

In tissue sections, immunostaining for androgen receptor was predominant in the epithelium of all regions of the epididymis (Figs 3a-3d). Staining in the initial segment was conspicuous and more intense than in any other region of the epididymis, but staining in efferent ducts was faint (Fig. 3a). In the corpus and cauda epididymidis, some staining also was evident in smooth muscle associated with the duct. Staining was not observed in liver or when preimmune serum (Fig. 3e) or antiserum preadsorbed with the immunogen was substituted for primary antiserum.

The results for individual elutriations of tissue from each of the 3 regions for the 6 rams (Table 1) show that Fractions I and II were quite different, and that Fraction II was enriched for principal cells. In general, Fraction I contained more cells per unit volume than did Fraction II. Excluding data for the distal caput from Ram 128, for which distinct cellular fractions were not produced, the percentages of principal cells in samples from the central caput, distal caput and central corpus epididymidis were similar $(P>0.05)$ among regions.

For each of the 18 samples, the number of DHT receptors per $10^{6}$ cells was greater $(P<0.01)$ in Fraction II than in Fraction I (Table 1). When number of DHT receptors in Fraction II was expressed on a basis of $10^{6}$ principal cells, assuming that all DHT receptor was associated with principal cells, values for the central caput and distal caput were higher $(P<0.05)$ than those for the central corpus epididymidis (Table 2 ). Interactions of fraction by region of the epididymis were not significant.

Immunostaining of elutriated cells revealed only a few cells that were distinctly stained in cellular Fraction I, while some others stained faintly (Fig. 3f). For Fraction II, however, most cells were conspicuously stained (Fig. $3 \mathrm{~g}$ ). This staining pattern was similar in all 3 regions studied.

Table 1. Cellular yield, percentage of principal cells, and concentration of DHT receptor in cellular fractions from three regions of the epididymis of the ram

\begin{tabular}{|c|c|c|c|c|c|c|c|}
\hline \multirow{2}{*}{$\begin{array}{l}\text { Region of } \\
\text { epididymis }\end{array}$} & \multirow[b]{2}{*}{ Ram } & \multicolumn{2}{|c|}{$\begin{array}{l}\text { Total cells } \\
\left(10^{6} / \mathrm{ml}\right)\end{array}$} & \multicolumn{2}{|c|}{$\begin{array}{c}\text { Principal cells } \\
(\%)\end{array}$} & \multicolumn{2}{|c|}{$\begin{array}{l}\text { DHT receptor } \\
\left(\mathrm{fmol} / 10^{6} \text { cells }\right)\end{array}$} \\
\hline & & Fraction I & Fraction II & Fraction I & Fraction II & Fraction I & Fraction II \\
\hline \multirow{7}{*}{$\begin{array}{r}\text { Central } \\
\text { caput }\end{array}$} & 128 & 32 & 9 & 8 & 70 & $9 \cdot 3$ & 37 \\
\hline & 129 & 52 & 7 & 12 & 76 & $5 \cdot 7$ & 47 \\
\hline & 130 & 74 & 18 & 6 & 60 & $5 \cdot 2$ & 29 \\
\hline & 131 & 28 & 7 & 10 & 63 & $10 \cdot 6$ & 43 \\
\hline & 132 & 52 & 18 & 12 & 55 & $5 \cdot 7$ & 25 \\
\hline & 133 & 63 & 24 & 10 & 57 & $5 \cdot 1$ & 14 \\
\hline & Mean & 50 & 14 & 10 & 63 & 6.9 & 32 \\
\hline \multirow{7}{*}{$\begin{array}{l}\text { Distal } \\
\text { caput }\end{array}$} & $128^{*}$ & 62 & 52 & 38 & 45 & ND & ND \\
\hline & 129 & 26 & 6 & 7 & 68 & $11 \cdot 3$ & 50 \\
\hline & 130 & 71 & 6 & 7 & 60 & $6 \cdot 7$ & 50 \\
\hline & 131 & 74 & 12 & 8 & 64 & $5 \cdot 6$ & 34 \\
\hline & 132 & 87 & 10 & 6 & 77 & $4 \cdot 3$ & 47 \\
\hline & 133 & 42 & 13 & 6 & 76 & $8 \cdot 5$ & 27 \\
\hline & Mean & 60 & 9 & 7 & 69 & $7 \cdot 3$ & 42 \\
\hline \multirow{7}{*}{$\begin{array}{l}\text { Central } \\
\text { corpus }\end{array}$} & 128 & 42 & 15 & 5 & 69 & $8 \cdot 5$ & 23 \\
\hline & 129 & 85 & 30 & 10 & 77 & $5 \cdot 1$ & 13 \\
\hline & 130 & 136 & 24 & 9 & 73 & $4-0$ & 16 \\
\hline & 131 & 72 & 16 & 6 & 63 & $5 \cdot 7$ & 19 \\
\hline & 132 & 111 & 35 & 14 & 81 & 3.9 & 15 \\
\hline & 133 & 131 & 25 & 5 & 71 & $3 \cdot 5$ & 16 \\
\hline & Mean & 96 & 24 & 8 & 72 & $5 \cdot 1$ & 17 \\
\hline
\end{tabular}

*Values for this sample were excluded from mean values, because of failure to isolate distinct fractions; ND= not determined. 
Table 2. Estimated concentrations of DHT receptor in principal cells or in 'other' cells from ram epididymis*

\begin{tabular}{lccc}
\hline $\begin{array}{c}\text { Region of } \\
\text { epididymis }\end{array}$ & Ram & $\begin{array}{c}\text { Principal cells } \\
\text { in Fraction II } \\
\text { (fmol/106 cells) }\end{array}$ & $\begin{array}{c}\text { 'Other' cells in } \\
\text { in Fraction I } \\
\text { (fmol/10 cells) }\end{array}$ \\
\hline Central caput & 128 & 52 & $5 \cdot 6$ \\
& 129 & 63 & $0 \cdot 0$ \\
& 130 & 49 & $2 \cdot 4$ \\
& 131 & 68 & $4 \cdot 2$ \\
& 132 & 46 & $0 \cdot 2$ \\
& 133 & 24 & $0 \cdot 1$ \\
& Mean & 50 & $2 \cdot 1$ \\
& 129 & 74 & $6 \cdot 6$ \\
& 130 & 86 & $0 \cdot 7$ \\
& 131 & 53 & $1 \cdot 5$ \\
& 132 & 61 & $0 \cdot 7$ \\
& 133 & 36 & $6 \cdot 6$ \\
& Mean & 62 & $3 \cdot 2$ \\
& 128 & 33 & $7 \cdot 2$ \\
& 129 & 17 & $3 \cdot 8$ \\
& 130 & 23 & $2 \cdot 1$ \\
& 131 & 31 & $4 \cdot 1$ \\
& 132 & 19 & $1 \cdot 4$ \\
& 133 & 23 & $2 \cdot 5$ \\
& Mean & 24 & $3 \cdot 5$ \\
\hline
\end{tabular}

${ }^{*}$ Calculated assuming that DHT receptor was found only in principal cells in Fraction II, and that DHT receptor not present in principal cells was equally distributed among all cells in the 'other' population of Fraction I regardless of cell type or cell volume.

Immunostaining of elutriated cells was not observed when preimmune serum (Fig. $3 \mathrm{~h}$ ) or antiserum preadsorbed with synthetic peptide (Fig. 3i) was substituted for primary antiserum.

\section{Discussion}

Based on Papanicolaou-stained slides, principal cells averaged 63,69 and $72 \%$ of the total population of cells in Fraction II from elutriations for the central caput, distal caput and central corpus epididymidis. These values were considerably lower than values reported by Wagley $e t$ al. (1984), although the procedures used for elutriation and determination of the percentage of principal cells were essentially identical. This difference was probably due to the batch of enzyme, and the facts that in the present study more tissue was dissociated per flask and more cells were loaded into the elutriation system.

Because of the obvious enrichment of Fraction II for principal cells (Table 1), the approximately 5-fold greater number of DHT receptors per cell in Fraction II, and immunolocalization of receptor in most cells in Fraction II (Fig. 3), we conclude that most DHT receptors are located in principal cells. However, some cells in the 'other' population (primarily smooth muscle cells and fibroblasts) probably contain a low level of androgen receptor, as evidenced by immunostaining of some non-epithelial cells. If all principal cells in Fractions I and II have the same number of receptors, the 'other' cells must have contained about 2.9 fmol DHT receptor per $10^{6}$ cells, regardless of region (Table 2), as compared to 50,62 , or $24 \mathrm{fmol}$ per $10^{6}$ principal cells in the central caput, distal caput, or central corpus epididymidis, respectively. Alternatively, about $5 \%$ of the 'other' cells in Fraction I have a number of DHT receptors similar to that for principal cells in the caput epididymidis. In either case, most epididymal DHT receptors must be localized in principal cells. 
This conclusion is supported by immunohistochemical localization of androgen receptor, using the same antiserum, in rat epididymal tissue (Sar \& Wilson, 1989).

The concentration of DHT receptor for cells in Fraction II was greater for the central caput and distal caput than the central corpus epididymidis. This probably reflects a true regional difference in receptor number per principal cell (930 in central or distal caput $v s 400$ in central corpus epididymidis for Fraction II), since the percentage of principal cells (of all somatic cells) in Fraction II was similar for all regions (Table 1). The current results are consistent with our previous finding that the concentration ( $\mathrm{fmol} / \mathrm{mg}$ protein) of DHT receptor in extracts of whole epididymal tissue, collected at a similar time of year, was higher in the central caput and proximal corpus epididymidis than in the proximal caput, distal corpus or cauda epididymidis (Tekpetey \& Amann, 1988a). The apparent discrepancy between intense immunostaining for androgen receptor in the initial segment (Fig. 1) and the relatively low tissue concentration of receptor in the proximal caput (Tekpetey $\&$ Amann, 1988a) probably results from inclusion of the efferent ducts in their tissue preparation. Although our immunocytochemical observations are not quantitative, and cannot be intepreted as concentration DHT receptor per $10^{6}$ principal cells or per milligram protein, they clearly suggest that the epithelium of the initial segment contains considerable androgen receptor. However, there probably is little DHT in the initial segment or proximal caput epididymidis since there is little $5 \alpha$-reductase in these tissues (Amann, 1987), although testosterone should be available. Affinity of the androgen receptor in ram epididymal tissue for testosterone is only $10 \%$ of that for DHT (Tekpetey \& Amann, 1988a). Collectively, these results support the conclusion that in rams the region between the central caput and proximal corpus epididymidis probably is most dependent on androgen stimulation, presumably for functions important in providing a milieu essential for sperm maturation.

This research was supported by NIH Grant HD-14501 and EPA Contract CR-812725-01. We thank Dr F. S. French and Dr E. M. Wilson for a generous gift of antibody AR1-52 for the androgen receptor and synthetic peptide for adsorbing the antiserum; and Ms J. S. Palmer for skilled technical assistance.

\section{References}

Amann, R.P. (1987) Function of the epididymis in bulls and rams. J. Reprod. Fert., Suppl. 34, 115-131.

Amann, R.P. (1988) Maturation of spermatozoa. Proc. Ilth Int. Congr. Anim. Reprod. \& AI, Dublin 5, $320-328$.

Amann, R.P. \& Hammerstedt, R.H. (1976) Binding of steroids by intact bovine sperm. Biol. Reprod. 15, $670-677$.

Amann, R.P., Marengo, S.R. \& Brown, D.V. (1987) Steroidogenesis and testosterone metabolism in cultured principal cells from the ram epididymis. $J$. Androl. 8, 238-246.

Brooks, D.E. (1987) Developmental expression and androgenic regulation of the mRNA for major secretory proteins of the rat epididymis. Molec. cell. Endocrinol. 53, 59-66.

Brooks, D.E., Means, A.R., Wright, E.J., Singh, S.P. \& Tiver, K.K. (1986) Molecular cloning of the cDNA for two major androgen-dependent secretory proteins of 18.5 kilodaltons synthesized by the rat epididymis. J. biol. Chem. 26, 4956-4961.

Danzo, B.J. \& Eller, B.C. (1975) Androgen binding to cytosol prepared from epididymides of sexually mature castrated rabbits: evidence for a cytoplasmic receptor. Steroids 25, 507-523.
Danzo, B.J., Orgebin-Crist, M.C. \& Toft, D.O. (1973) Characterization of a cytoplasmic receptor for $5 \alpha$ dihydrotestosterone in the caput epididymis of intact rabbits. Endocrinology 92, 310-317.

Hansson, V., Djoseland, O., Reusch, E., Attramadal, A. \& Torgersen, O. (1973) Intracellular receptors for $5 \alpha$ dihydrotesterone in the epididymis of adult rats. Comparison with the androgenic receptor in the ventral prostate and the androgen binding protein (ABP) in the testicular and epididymal fluid. Steroids 22, $19-23$.

Klinefelter, G.R. \& Amann, R.P. (1980) Metabolism of testosterone by principal and basal cells isolated from the rat caput epididymidis. Biol. Reprod. 26, 885-901.

Ritzen, E.M., Nayfeh, S.N., French, F.S. \& Dobbins, M.C. (1971) Demonstration of androgen binding components in rat epididymis cytosol and comparison with binding components in prostate and other tissues. Endocrinology 89, 143-151.

Robaire, B. \& Hermo, L. (1988) Efferent ducts, epididymis and vas deferens: structure, function and their regulation. In The Physiology of Reproduction, $\mathrm{pp}$. 999-1080. Eds E. Knobil \& J. D. Neill. Raven Press, New York.

Sar, M. \& Wilson, E.M. (1989) Immunohistochemical 
localization of androgen receptors in rat brain, pituitary and reproductive tissues, mouse testis and human prostate. Endocrinology 124 (Suppl.), 69, abstr.

Schleicher, G., Drews, U., Stumpf, W.E. \& Sar, M. (1984) Differential distribution of dihydrotestosterone and estradiol binding sites in the epididymis of the mouse. An autoradiographic study. Histochemistry 81, 139-147.

Statistical Analysis System User's Guide (1982) Statistics. SAS Institute Inc., Cary, NC.

Tan, J., Joseph, D.R., Quarmby, V.E., Lubahn, D.B., Sar, M., French, F.S. \& Wilson, E.M. (1988) The rat androgen receptor: Primary structure, autoregulation of its messenger ribonucleic acid, and immunocytochemical localization of the receptor protein. Molec. Endocr. 2, 1276-1285.
Tekpetey, F.R. \& Amann, R.P. (1988a) Regional and seasonal differences in concentrations of androgen and estrogen receptors in ram epididymal tissue. Biol. Reprod. 38, 1051-1060.

Tekpetey, F.R. \& Amann, R.P. (1988b) Effects of exogenous melatonin prior to the breeding season on testis weight and epididymal androgen receptors in rams. Dom. Anim. Endocrinol. 5, 257-264.

Wagley, L.M., Versluis, T.D., Brown, D.V. \& Amann, R.P. (1984) Culture of principal cells from the ram epididymis. A comparison of the morphology of principal cells in culture and in situ. J. Androl. 5, $389-408$.

Received 3 February 1989 